\title{
Living on Healthy Rhythms to Overcome Cancer: A Public Therapeutic
}

\author{
Akbar Nikkhah*
}

Chief Highly Distinguished Professor, Department of Animal Sciences, Faculty of Agricultural Sciences, University of Zanjan, Foremost Principal Highly Distinguished Elite-Generating Scientist, National Elite Foundation, Iran

\begin{abstract}
This policy article sets the stage for birth of a novel public science that establishes living on rhythms to minimize risks of different cancers in the overly busy modern life. Keeping body and mind away from irregularities before incursion in genes, proteomes, metaboloms, and cells and thus in the incognizant human societies of the new times, must be highly pursued. Healthy rhythms in working, eating, drinking, sleeping, entertaining, socializing, sciencing, modernizing, exercising, travelling, and contemplating must be created and maintained for a life style to not be threatened by cancer.
\end{abstract}

Keywords: Rhythm, Cancer, Science, Public health.

\section{INTRODUCTION}

Cancer is fundamentally defined and caused by obstinate irregularities in cell physiology that may or may not stem from genetics. However, the much unknown about the nature of cancer and the unexplored mechanisms possibly underlying oncogenesis suggest that understanding cancer aetiology should be much simpler than thought [1-4]. This article was developed on the insight that complexity may not clutch long enough to cause irreversible losses in cell physiology or what is known as development of cancer. This suggests that cancer must not have too profound causes to be effectively and publicly worked on to prevent its seriously clinical and irrecoverable incidence. Therefore, a pragmatic approach was undertaken based on rhythmic characteristics of human life that necessitate synchronizing internal physiology with external environment [5].

\section{INNOVATIONS AND DISCUSSION}

Life in any form in essence has a rhythmic development [6]. The rhythmicity in circadian and circannual periods of life shapes animal and human physiology [7]. Thus, maintaining regularity and synchrony between internal human cell and tissue physiology with external environmental cues (e.g., timing of working, eating, drinking, travelling, socializing, entertaining, sleeping, exercising, photoperiod and other related life style effectors) is a

*Address correspondence to this author at the Chief Highly Distinguished Professor, Department of Animal Sciences, Faculty of Agricultural Sciences, University of Zanjan, Foremost Principal Highly Distinguished Elite-Generating Scientist, National Elite Foundation, Iran; Tel: +98-24-35052801; Fax: +98-2435053202; E-mail: anikkha@yahoo.com, nikkhah@znu.ac.ir main reason to stay healthy and on good shape in body and mind. This is a simple but highly integrated science that must be educated, reiterated, refined and persistently practiced for healthy styles to be born in today's overly busy and stressed modern life. Spending irregularly more time for any of the above activities/rhythms than others smashes the balance required for healthy regularities in cell function. That is especially the case in brain and central nervous systems cells. The devastating diseases of the new times that human encounters more often than before must be in ways a result of such uncontrolled irregularities in main rhythms of life style attributes.

The overmodernized man must gain back and practice the natural style of living at least in determining parts. Living close to nature in life style and its circadian components is what maintenance of healthy rhythms demands. Simply put, life quality cannot be improved at the presence of major asynchronies between rhythms of human physiology and natural patterns originating from diurnal, nocturnal, seasonal, and circannual rhythms of life. Working, eating, drinking, travelling, socializing, entertaining, sleeping, exercising, exposure to photoperiod and other contributors of life style must not only be conducted in right length but also at optimal times of any rhythmic episode from circadian through monthly, circannual, and decadal periods. Future research and contemplation will expand the new pragmatic science should a relief from deadly cancers be aimed to be secured.

\section{IMPLICATIONS}

The major life affairs contributing to life style, regardless of place and time of living, need to be set on 
healthy circadian, monthly and indeed circannual rhythms to minimize chances of uncontrollable irregularities in cell physiology. Creating balance and synchrony between rhythms of human life style with patterns of the external environment will not authorize penetrating the irregularities into genes and their omical generational properties. Living a healthy cancerfree life, thus, requires establishing and maintaining regular rhythms of life style constituents that fit those of nature.

\section{ACKNOWLEDGEMENTS}

Gratefully thanked are the Ministry of Science Research and Technology, National Elite Foundation, and University of Zanjan for supporting the author's global programs of optimizing science edification in the third millennium.

\section{REFERENCES}

[1] Nikkhah A. Eating time modulations of physiology and health: life lessons from human and ruminant models. Iranian J Basic Med Sci 2012; 15(4): 787-794.

[2] Nikkhah A. Establishing rhythmic regularities in cell physiology: A novel global program to thwart cancer. J Nutr Health Food Eng 2015; in press.

[3] Nikkhah A. Discovering the right time to take food to smash diabetes. J Diabetes Res Ther 2015; in press.

[4] Nikkhah A. Breast health progress through exercise-driven lactation: A pragmatic bioprocess to prevent cancer. J Bioprocess Biotechniq 2015; in press. http://dx.doi.org/10.4172/2155-9821.1000e127

[5] Nikkhah A. Time of Feeding an Evolutionary Science. Lap Lambert Publishing, GmbH \& Co. KG, Germany 2012; ISBN 978-3-8473-3260-2.

[6] Sehgal A. Molecular Biology of Circadian Rhythms. John Wiley \& Sons, Inc., Hoboken, NJ, USA 2004. http://dx.doi.org/10.1002/0471459186

[7] Nikkhah A. Science of eating time: A novel chronophysiological approach to optimize glucose-insulin dynamics and health. J Diabetes Mellitus 2011; 2(1): 8-11. http://dx.doi.org/10.4236/jdm.2012.21002

[8] Nikkhah A. Eating timing and diabetes. Int J Diabetol Vas Dis Res 2014; 2: 101. 